\title{
The hospitality industry development factors (case of St. Petersburg)
}

\author{
Oksana Pirogova ${ }^{1}$, Sergey Shanygin ${ }^{2}$, Tatiana Lavrova $^{3}$, and Vladimir Plotnikov ${ }^{3, *}$ \\ ${ }^{1}$ Peter the Great St. Petersburg Polytechnic University, 29 Polytechnicheskaya str., St. Petersburg, \\ Russia, 195251 \\ ${ }^{2}$ St. Petersburg State University, department of statistics, accounting and audit, 199034, 7-9 \\ Universitetskaya emb., St. Petersburg, Russia \\ ${ }^{3}$ St. Petersburg State University of Economics, 191023, 21 Sadovaya str., St. Petersburg, Russia
}

\begin{abstract}
The hospitality industry is the unity of all cooperating organizations, each of which performs certain functions aimed at meeting the needs of consumers. The purpose of the article is to review the hotel market of St. Petersburg in the pre-pandemic period. During the research, methods of system and economic analysis, statistical structural and dynamic analysis, correlation and regression analysis were used. To achieve this goal, the characteristics and lists of services of hotels of the main categories are structured. It analyses the key market indicators, such as occupancy and hotel room growth, the distribution of room stock by category, the ratio of tariffs for rooms in hotels of different categories, as well as tourist flow in the context of domestic and foreign citizens. The distribution of domestic and foreign tourists by districts of the city is considered, preferences are revealed. The analysis of the dynamics of changes in the main parameters of the market, including specific indicators, is carried out, demand and supply are compared. It is established that hotels in recent years have carried out activities to attract additional tourists. It is concluded that hotels of different categories did not have time to adapt to the increase in the number of tourists. The characteristics of the market that presumably influence the value of the Gross regional Product of the city are identified, and regression models are compiled. Assumptions are made about the trends in the development of the hotel market in St. Petersburg.
\end{abstract}

\section{Introduction}

The modern economy is in the stage of radical transformation caused by a complex of technological, political, demographic, social and other reasons [1-8, etc.]. In the structure of the economy, one should single out the priority development sectors. Their dynamics are transforming the structure of the economy. Therefore, more attention should be paid to these sectors in research. One of such sectors is tourism [9]. The problems of its development (in terms of the hospitality industry) are the object of study in this article.

\footnotetext{
*Corresponding author: plotnikov_2000@mail.ru.
} 
More recently, the hotel business in St. Petersburg has been rapidly developing. The quality of service, interior design, and staff qualification improved significantly. Tourists and city dwellers could always choose a suitable option for themselves, depending on their preferences and income level. The hospitality industry is about not only a human approach to service, but also providing coordinated technical issues in customer service (Wi-Fi connectivity, high quality phone calls, and much more), alerting about customer desires, technologies for fast processing and ordering. 2019 was the most successful year for the hospitality industry in St. Petersburg. A record tourist flow of 10.4 million people contributed to an increase in the occupancy rate of St. Petersburg hotels up to $69 \%$.

Over the past year, the hospitality industry of St. Petersburg was replenished with 13 new hotels, the total number of rooms in which is more than 850.2020 was also supposed to be very successful for hoteliers, however, because of travel bans due to COVID-19, the cancellation of large-scale events such Like the SPIEF and Euro 2020, the industry is currently experiencing difficult times: the number of clients has decreased, profits are declining, and many establishments are forced to close [10].

In the first quarter of 2020, the growth of new hotels in the St. Petersburg market remained at the same level as compared to the previous quarter (Figure 1).

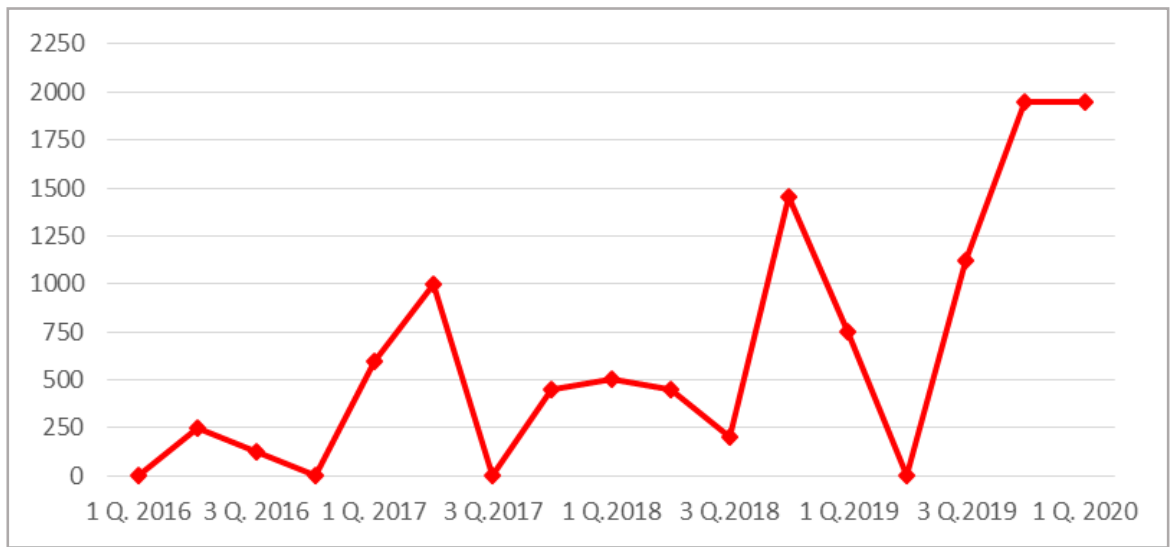

Fig. 1. The increase in the number of rooms in St. Petersburg [2].

The market volume at the end of the quarter is about 41.3 thousand rooms and apartments of various classes. This figure should be significantly higher, but due to the current epidemiological situation in the world, most of the hotels that planned to start operating in the first quarter of 2020 have postponed their opening dates to next year. This line of business is based on the principles of hospitality - the ability to make the client feel that he is happy, to show him respect and courtesy with dignity. The hospitality industry is an integral part of the tourism and hospitality industry [11].

\section{Materials and methods}

The main condition for the effective operation of a modern hospitality enterprise is the ability and ability to quickly respond to changes and adapt to them. In addition, this is their prerequisite for development and further existence. Hotels are the most expensive place to stay. Here the visitor is offered a large range of various services. Hotels are divided into some categories (Table 1).

Apartments are a new term in the hotel industry. Life is very much like living in a standard apartment in this room. For this reason, unlike hotels, apartments should have a 
kitchen with the necessary utensils and a minimum of necessary equipment - a refrigerator, a stove for cooking and an extractor hood [12]. Hotel apartments are also divided into several additional subgroups (Table 2).

Table 1. Categories of hotels.

\begin{tabular}{|c|c|c|}
\hline Category & Motto & Description, services \\
\hline $5^{*}$ & Luxury & $\begin{array}{l}\text { Location: in the city center; } \\
\text { Swimming pool, SPA; } \\
\text { Individual attention - doorman, butler; } \\
\text { Developed infrastructure (beauty salons; fitness centers, } \\
\text { etc.); } \\
\text { Additional services (serving breakfast and dinner in the } \\
\text { room, laundry and dry cleaning, taxi call, etc.) }\end{array}$ \\
\hline $4 *$ & $\begin{array}{l}\text { Dignity and } \\
\text { comfort }\end{array}$ & $\begin{array}{l}\text { Rooms for } 1-2 \text { people; } \\
\text { All the amenities in the room; } \\
\text { 24-hour restaurant; } \\
\text { Daily cleaning and linen change; } \\
\text { Concierge, luggage service }\end{array}$ \\
\hline $3 *$ & $\begin{array}{l}\text { Necessary comfort } \\
\text { for little money }\end{array}$ & $\begin{array}{l}\text { Rooms for } 1-2 \text { people; } \\
\text { All the amenities in the room; } \\
\text { Restaurant: breakfast, lunch and dinner }\end{array}$ \\
\hline $2 * \& 1 *$ & $\begin{array}{l}\text { No frills, only the } \\
\text { essentials }\end{array}$ & $\begin{array}{l}\text { Facilities on the floor; } \\
\text { Shared kitchen }\end{array}$ \\
\hline
\end{tabular}

Table 2. Categories of hotel apartments.

\begin{tabular}{|c|c|c|c|c|c|}
\hline \multirow{2}{*}{ Name } & Feature & \multicolumn{2}{|c|}{ Appointment } & Availability \\
\cline { 3 - 5 } & $\begin{array}{c}\text { Rent } \\
\text { of add. } \\
\text { services } \\
\text { from 1-5 } \\
\text { operator }\end{array}$ & Rental & Residence & \\
\hline $\begin{array}{c}\text { Hotel } \\
\text { apartments }\end{array}$ & $\begin{array}{c}\text { A hotel in which the share of } \\
\text { apartments does not exceed } \\
10 \% \text { of the total number of } \\
\text { rooms }\end{array}$ & + & - & - & $3-5$ \\
\hline Aparthotels & $\begin{array}{c}\text { Hotel with room categories } \\
\text { apartments or studio }\end{array}$ & + & - & - & $3-5$ \\
\hline $\begin{array}{c}\text { Condo hotels } \\
\text { Complex of apartments with a } \\
\text { service structure of a 5-star } \\
\text { hotel }\end{array}$ & + & + & + & $4-5$ \\
\hline $\begin{array}{c}\text { Residential } \\
\text { apartments }\end{array}$ & $\begin{array}{c}\text { Low maintenance apartments, } \\
\text { commercial real estate }\end{array}$ & - & + & + & $1-2$ \\
\hline $\begin{array}{c}\text { Service } \\
\text { apartments }\end{array}$ & $\begin{array}{c}\text { Residential apartments } \\
\text { managed by a hotel operator } \\
\text { with a service higher than in } \\
\text { residential apartments, but } \\
\text { lower than in hotels }\end{array}$ & + & + & + & $2-3$ \\
\hline $\begin{array}{c}\text { Apartments in } \\
\text { a } \\
\text { multifunctional } \\
\text { complex }\end{array}$ & $\begin{array}{c}\text { A complex of apartments as } \\
\text { part of a multifunctional } \\
\text { complex intended for long- } \\
\text { term rent }\end{array}$ & + & + & + & $4-5$ \\
\hline
\end{tabular}

Accommodation in an apart-hotel combines not only hotel service, but also home comfort and pleasant rates. A whole range of advantages also characterizes accommodation in apart-hotels [13]:

1) Guests have access to a separate kitchen; 
2) Absolute freedom in their actions. Friends and acquaintances can come to visit without any problems;

3) The large area of the room in the apart-hotel can accommodate a large group of people;

4) Long term rent. Rooms in these hotels can be rented for a long time, the terms of placement can be any;

5) Renting a room in an apart-hotel will cost less than in a hotel;

6) If you wish, you are given the opportunity to resort to hotel services, such as laundry, food delivery and room cleaning;

7) In the presence of large enough rooms, it becomes possible to choose a room with a beautiful view outside the window;

8) You can always, if you wish, use the services provided by the beauty salon, do fitness, and enjoy SPA procedures and many other services.

Thus, hotels include the widest variety of services and are the most expensive type of accommodation. The apartments are a budgetary way of accommodation and provide a minimum range of services.

\section{Results and discussion}

In the structure of the supply of the hotel industry market in St. Petersburg, the largest share so far belongs to $3 *(25 \%)$ and $4 *(22 \%)$ hotels, however, the share of apartments, which are becoming more and more popular every year, is also significant and amounts to $21 \%$ (Figure 2) [14].

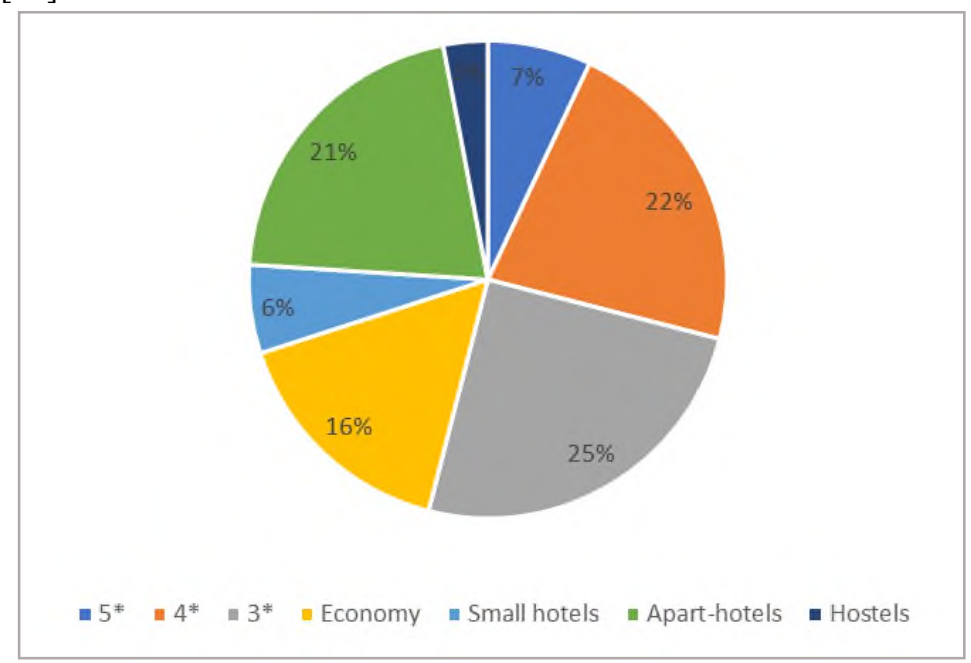

Fig. 2. Distribution of room stock by hotel category.

During the pandemic, the occupancy rate of all hotels, without exception, decreased several times compared to the values traditional for this time of year. The occupancy rate of quality hotels decreased almost 10 times and amounted to only 7\% (Figure 3 ). Consider the main trends in the development of the hotel industry in St. Petersburg in 2013-2019. The values of all cost indicators were preliminarily presented at constant prices of 2013; to exclude inflation, the RF GDP (for GRP) and the RF CPI (for the rest) were used [15].

During this period, the tourist flow of St. Petersburg grew almost evenly: Russian tourists - from 3.3 to 5.5 million people (on average by $8.9 \%$ per year), foreign - from 3.0 to 4.9 million people (by $8.5 \%$ per year). As a result, the total tourist flow increased from 6.3 to 10.4 million people. Hotel occupancy in St. Petersburg increased from 64 to $74 \%(2.4 \%$ 
per year). At the same time, the number of rooms in collective accommodation facilities increased from 24.4 to 44.5 thousand units (by $10.6 \%$ annually), the number of beds in hotels and similar accommodation facilities increased from 62.3 to 105.0 thousand units (by $9.1 \%$ per year), the area of the room stock increased from 651.0 to 982.3 thousand square meters, on average its growth was $7.1 \%$ annually. The number of overnight stays in collective accommodation facilities also increased from 8.8 million in 2013 to 16.0 million in 2019 [16].

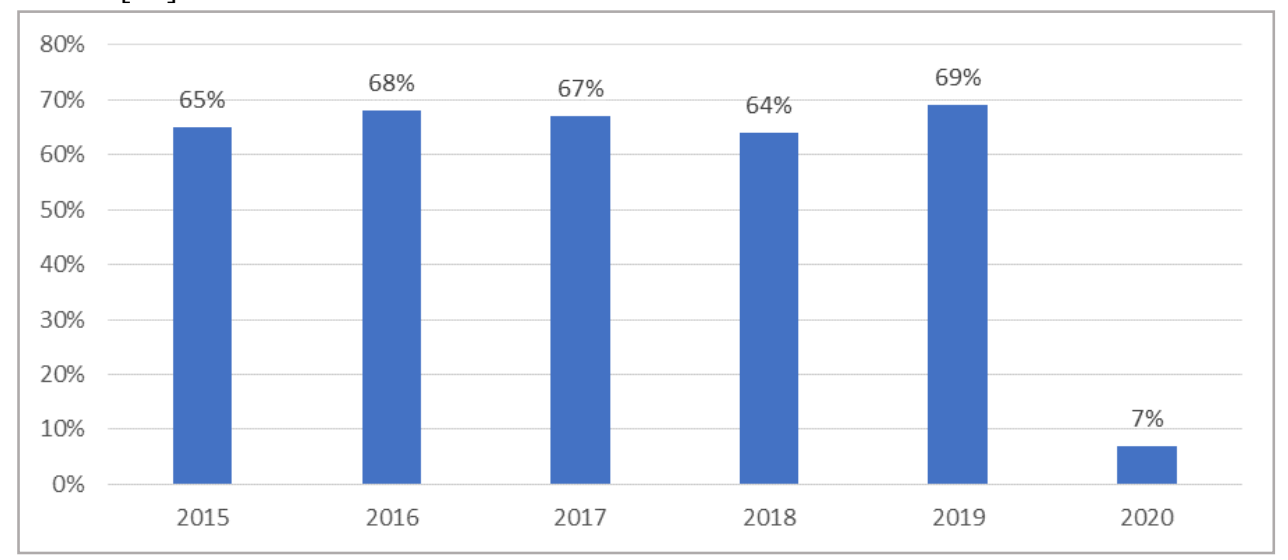

Fig. 3. Loading of the room stock of hotels in St. Petersburg, category 3-5*, \%.

However, the trends in the change in the main ratios of the characteristics of the flow of tourists and accommodation facilities in St. Petersburg are somewhat different, so from a comparison of the number of Russian and foreign citizens accommodated in hotels and similar accommodation facilities, and the total number of overnight stays in them, we can conclude that the average length of stay of one person for the considered period decreased from 3.1 to 2.6 nights (days). The relationships associated with the area of the room fund (ARF) are shown in Figure 4 [17].

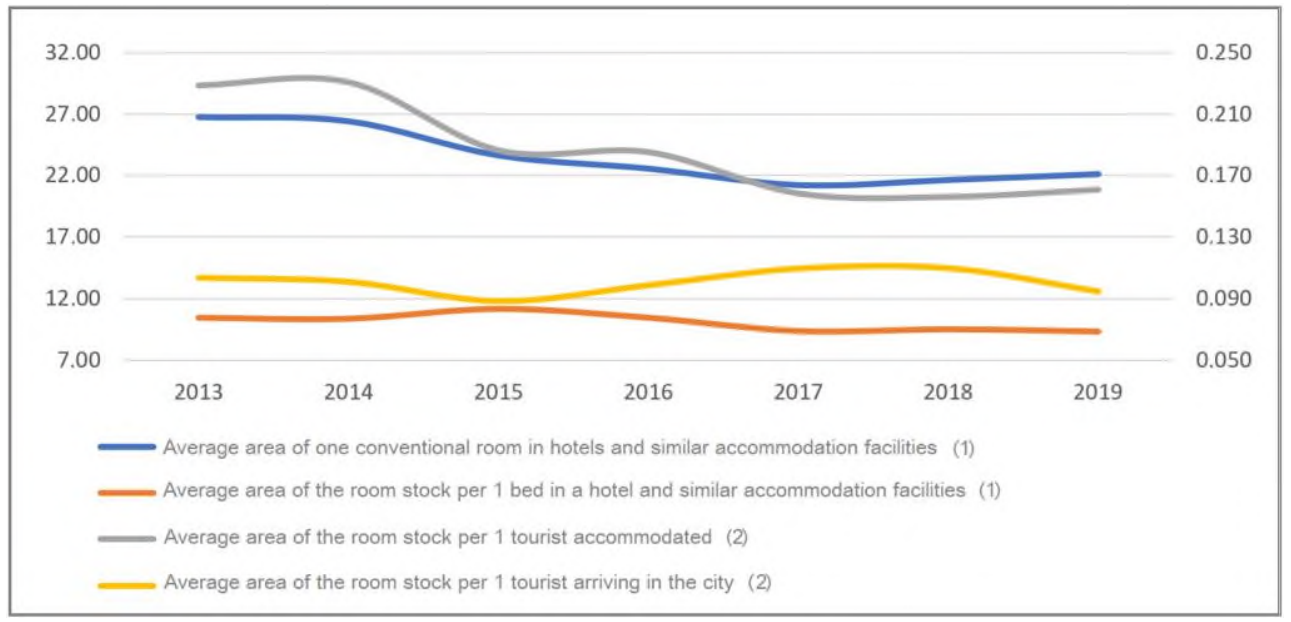

Fig. 4. Dynamics of individual ratios of parameters of tourist traffic and accommodation facilities, sq. m; (1) - left axis; (2) - right axis.

The values of almost all four indicators shown in the figure during the period under consideration decreased with slight fluctuations. The average rate of their decline was 3.1, 
$1.8,5.7$ and $1.5 \%$ (respectively, in the order of mention in the figure). It can be concluded that the quality parameters of St. Petersburg accommodation facilities deteriorated relatively uniformly during this period. In other words, the hotel industry in St. Petersburg did not have time to adapt to the increase in tourist traffic [18].

The rates for accommodation in hotels and similar accommodation facilities in St. Petersburg also changed in the same direction (Figure 5) [19]. The rates of their decline were $3.6,2.5$ and $1.6 \%$ (respectively, in the order of mention in the figure). It can be stated that the parameters of accommodation facilities may have become more rational for shortterm accommodation, but the cost of living in them, according to the authors, is overstated.

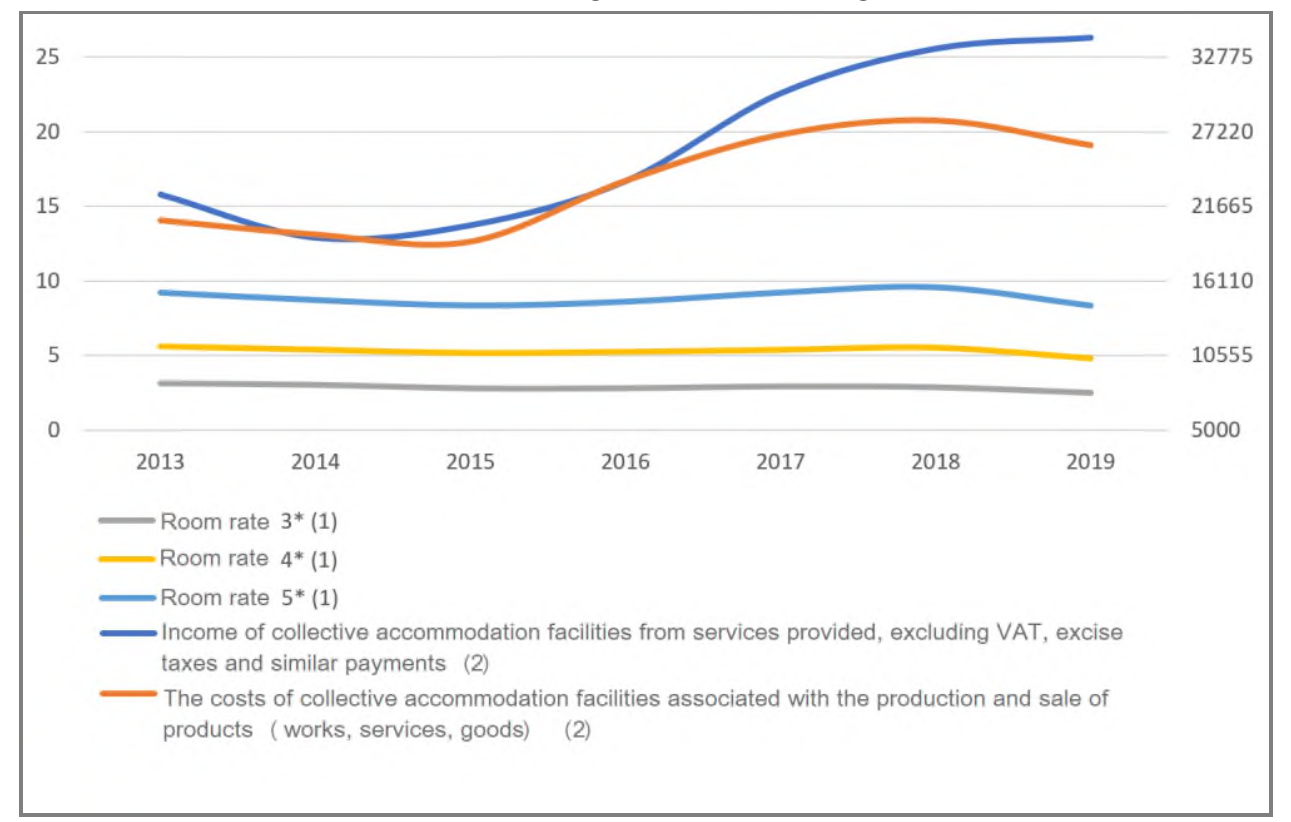

Fig. 5. Dynamics of rates for rooms of three main categories in St. Petersburg (thousand rubles per day), income and costs of collective accommodation facilities (thousand rubles); (1) - left axis; (2) right axis.

The dynamics of income and expenses of hotels and similar collective accommodation facilities in St. Petersburg is also shown in Fig. 5. Before the introduction of economic sanctions against the Russian Federation in 2014-2015, they decreased, after that, they began to grow rather rapidly until 2018, then revenues continued to grow slightly, and costs began to decrease $[20,21]$. Over the entire period, incomes increased by about 1.52 times, and expenses - by 1.27 times (in constant prices of 2013), which indicates a relatively progressive, in terms of value, development of this sector of the St. Petersburg economy.

Next, we will consider the structure of accommodation of visiting citizens by districts of St. Petersburg according to information for 2015-17. Let us present the initial values of the indicators in shares of the total number of people placed, separately for citizens of the Russian Federation and separately for foreign citizens (Figure 6) [22].

Structures 2015 and 2017 differ slightly. The main areas of accommodation for foreign citizens are Admiralteisky, Vasileostrovsky, Moskovsky and Central: Russian citizens - the same areas and Kurortny. The shares of other districts do not exceed 5-6\%, but gradually their contribution begins to increase. It can be concluded that the historical part of the city attracts foreign citizens to St. Petersburg, despite the fact that the cost of accommodation in these areas is usually higher. Accordingly, it is advisable to continue building high-star hotels in these areas [23]. 

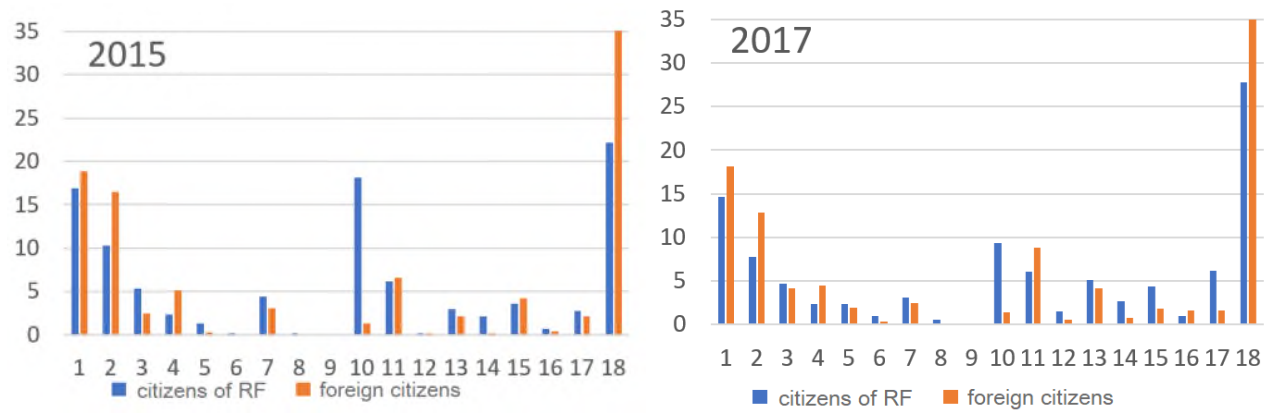

1 - Admiralteysky; 2 - Vasileostrovsky; 3 - Vyborgsky; 4 - Kalininsky; 5 - Kirovsky; 6 - Kolpinsky; 7 - Krasnogvardeisky; 8 - Krasnoselsky; 9 - Kronstadt; 10 - Kurortny; 11 - Moscovsky; 12 - Nevsky; 13 - Petrogradsky; 14 - Petrodvortsovy; 15 - Primorsky; 16 - Pushkin; 17 - Frunzensky; 18 - Central.

Fig. 6. Number of persons accommodated in collective accommodation facilities, $\%$.

In addition, we will consider how the development of the hotel and tourism sector of St. Petersburg affects the gross regional product (GRP) of the city. Due to the short observation period, the study of multiple correlation turned out to be impossible, the assessment of stationarity was not performed [20]. Based on the matrix of pair correlation, composed of the linear correlation coefficients of Pearson, indicators were identified (Table 3), possibly influencing $(r>0.75)$ on the GRP of St. Petersburg (million roubles). The fields of correlation of these indicators (x) with GRP (y) and the model are shown in Figure 7.

Table 3. Statistical significance of regression models.

\begin{tabular}{|l|c|c|}
\hline \multicolumn{1}{|c|}{ Indicator $(\boldsymbol{x})$} & $\boldsymbol{F}$ & $\begin{array}{c}\text { Statistical significance of F } \\
\text { and model parameters }\end{array}$ \\
\hline $\begin{array}{l}\text { 1. Number of rooms in collective } \\
\text { accommodation facilities, pcs. }\end{array}$ & 8.796 & Significant \\
\hline 2. Loading of hotels, \%. & 12.906 & Partial \\
\hline $\begin{array}{l}\text { 3. Number of Russian citizens accommodated } \\
\text { in collective accommodation facilities, people }\end{array}$ & 8.770 & Significant \\
\hline $\begin{array}{l}\text { 4. The number of foreign citizens } \\
\text { accommodated in collective accommodation } \\
\text { facilities, people }\end{array}$ & 8.539 & Significant \\
\hline $\begin{array}{l}\text { 5. Tourist flow (tourists from the Russian } \\
\text { Federation), million people }\end{array}$ & 15.470 & Significant \\
\hline $\begin{array}{l}\text { 6. Number of overnight stays in collective } \\
\text { accommodation facilities, units }\end{array}$ & 10.415 & . \\
\hline
\end{tabular}

When analysing the correlation dependences of other main indicators of this sector of the St. Petersburg economy, a direct mutual influence of tariffs for a room in pairs of categories was also revealed: $\left(3^{*}\right.$ and $\left.4^{*}\right),\left(4^{*}\right.$ and $\left.5^{*}\right)$ - the more one, the more the other, and vice versa $(r=0.92$ and $r=0.81$, respectively). This is probably due to the proximity of pricing mechanisms. The mutual influence in the pair $\left(3^{*}\right.$ and $\left.5^{*}\right)$ turned out to be significantly weaker $(\mathrm{r}=0.57)$. In addition, an inverse relationship was revealed for the $3^{*}$ and $4 *$ categories between rates per room and hotel occupancy - the higher the occupancy, the lower the rates, and vice versa $(r=-0.85$ and $r=-0.73$, respectively).

The same inverse influence manifested itself between the tariffs of the $3 *$ hotel category and the size of the tourist flow ( $r=-0.89$ for Russian citizens and $r=-0.72$ for foreign citizens). A similar effect of a lesser force was characteristic for hotels of the $4 *$ category $(r=-0.71$ for Russian citizens and $r=-0.57$ for foreign citizens). On the one hand, it can be 
assumed that the pricing mechanisms for these two categories of hotels are not fully market-based; on the other hand, the lower the rates, the higher the tourist flow and hotel occupancy. This pattern is fully consistent with the principles of market mechanisms, if the goal was to attract additional tourists. For hotels of the $5^{*}$ category, similar patterns were not revealed.

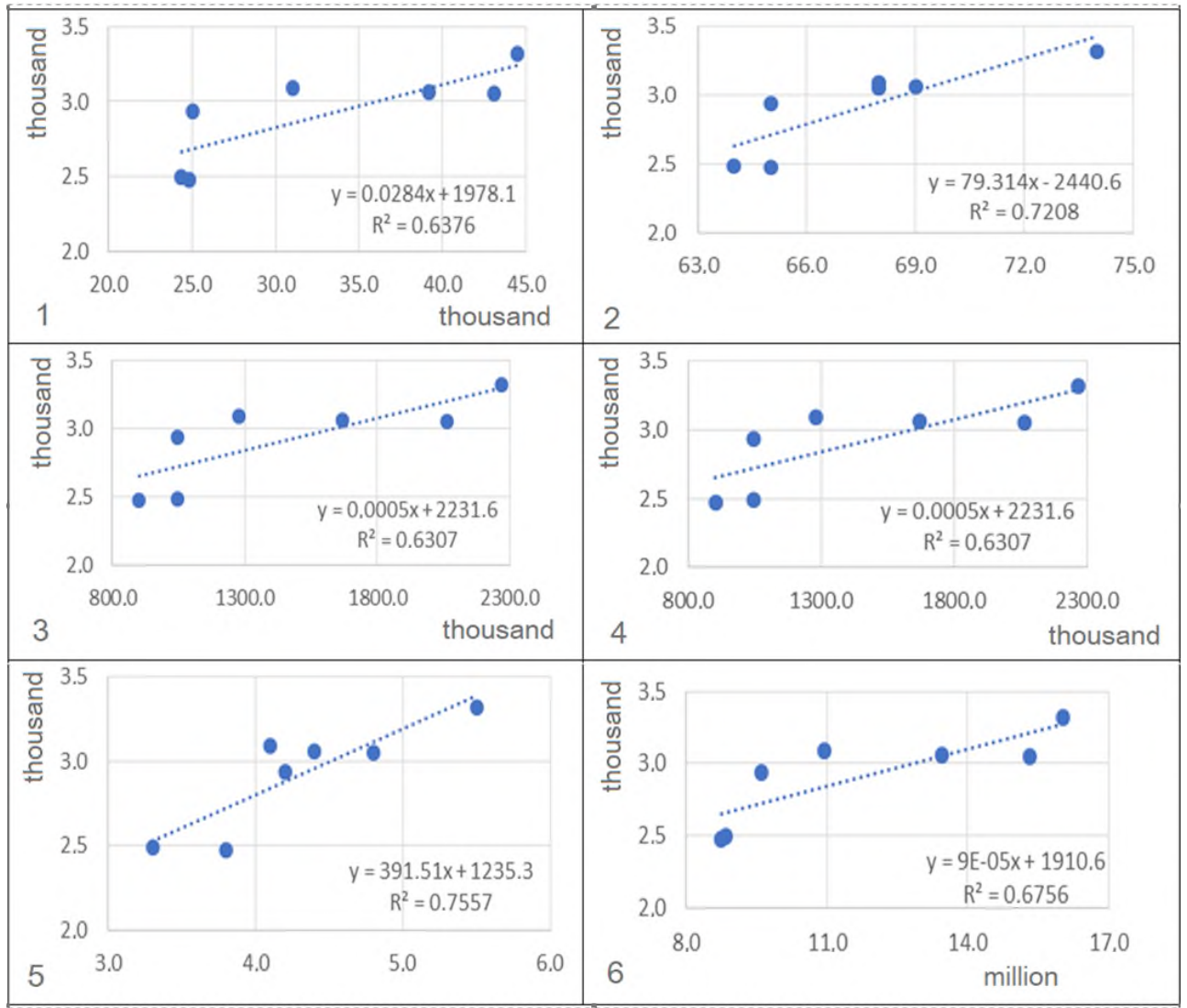

Fig. 7. Fields of correlation of the indicators indicated in the table with the GRP of St. Petersburg. (the field number corresponds to the indicator number).

\section{Conclusion}

According to the results of the analysis, the increase in the number of rooms in St. Petersburg in the period under consideration did not explicitly depend on any of the main parameters of the hotel and tourist industry and, presumably, was determined only by external factors. A decrease in the tourist flow is forcing hotel operators to revise rates, develop attractive systems of discounts and benefits for guests.

In order to "survive" in a pandemic, many hotels in St. Petersburg operate on one floor. Much emphasis is placed on long-term rentals (i.e. rooms are offered as an alternative to rental housing). The "self-isolation" tariff has appeared. It is primarily designed for those who returned from abroad and must withstand a fourteen-day quarantine in strict selfisolation. Renting an apartment for such a period is not profitable, and a hotel room is quite suitable for this. In addition, measures that can stimulate demand in this industry include the following measures: 
- Tax holidays, since a delay in payment may not save the business, because even after the movement restriction is lifted, it will need time to recover;

- Compensation of payments for utilities, subsidizing interest on existing loans;

- Zero tax rate on property and land for 12 months;

- Stimulating domestic demand in hotels of economy and middle price segment.

The new reality for the hospitality industry in 2020 became a watershed and tested the hospitality business for its strength and adaptability to new conditions. In 2021, the key task will be sanitary and epidemiological safety, which means that this segment should provide new safety. Some of the accommodation facilities will be closed in 2021, while the other part will become more technological and creative.

\section{References}

1. W. Bonefeld, European economic constitution and the transformation of democracy: On class and the state of law, European Journal of International Relations 21(4), 867-886 (2015)

2. T. Gries, W. Naudé, Entrepreneurship and structural economic transformation, Small Business Economics 34(1), 13-29 (2010)

3. S. Mavridis, Greece's economic and social transformation 2008-2017, Social Sciences 7(1), 9 (2018)

4. L. Melnyk, O. Kubatko, I. Dehtyarova, O. Matsenko, O. Rozhko, The effect of industrial revolutions on the transformation of social and economic systems, Problems and Perspectives in Management 17(4), 381-391 (2019)

5. V.A. Shumaev, D.E. Morkovkin, A.V. Nikonorova, V.N. Nezamaikin, I.L. Yurzinova, Innovative aspects of agritourism project management. Financial and Economic Tools Used in the World Hospitality Industry - Proceedings of the 5th International Conference on Management and Technology in Knowledge, Service, Tourism and Hospitality, SERVE 2017, 241-248 (2018)

6. S.A. Tolkachev, Network industrial policy in the age of the new industrial revolution, Zhournal Novoi Ekonomicheskoi Associacii 39(3), 155-162 (2018)

7. Y.V. Vertakova, M.G. Klevtsova, Y.S. Polozhentseva, Assessment of Asynchronous Development in the Implementation of the Main Areas of Regional Policy, Lecture Notes in Networks and Systems 111, 395-403 (2020) DOI 10.1007/978-3-030-39797-5_40

8. D.L. Yang, Economic transformation and its political discontents in China: Authoritarianism, unequal growth, and the dilemmas of political development, Annual Review of Political Science 9, 143-164 (2006)

9. T. Lavrova, V. Plotnikov, The development of tourism: the experience of Russia, MATEC Web of Conferences 170,01028 (2018) DOI 10.1051/matecconf $/ 201817001028$

10. J. Yoshida, The economic depreciation of real estate: Cross-sectional variations and their return implications, Pacific-Basin Finance Journal 61, 101290 (2020) DOI 10.1016/j.pacfin.2020.101290

11. O. Kravchenko, M. Leshchenko, D. Marushchak, Y. Vdovychenko, S. Boguslavska, The 8th International Conference on Monitoring, Modeling \& Management of Emergent Economy 65, 07004 (2019) DOI 10.1051/shsconf/20196507004

12. E. Voskresenskaya, L. Vorona-Slivinskaya, L. Achba, Environmental and Resource Economics 164, 09016 (2020) DOI 10.1051/e3sconf/202016409016 
13. O. Pirogova, E. Gorin, V. Plotnikov, The algorithms for the environmental finance based on adjusted present value models, E3S Web of Conferences 91, 08021 (2019) DOI 10.1051/e3sconf/20199108021

14. V. Plotnikov, O. Pirogova, Key Competencies as an Enterprise Value Management Tool, IBIMA 2018, 1716-1721 (2018)

15. M. Martín-Peña, J. Sánchez-López, E. Díaz-Garrido, Servitization and digitalization in manufacturing: the influence on firm performance, Journal of Business \& Industrial Marketing 35(3), 564-574 (2019) DOI 10.1108/JBIM-12-2018-0400

16. M.M. Hasan, Corporate life cycle, organizational financial resources and corporate social responsibility, Journal of Contemporary Accounting \& Economics 13, 20-36 (2017) DOI 10.1016/j.jcae.2017.01.002

17. K.M. Bakarich, M. Hossain, J. Weintrop, Different time, different tone: Company life cycle, Journal of Contemporary Accounting and Economics 15(1), 69-86 (2019) DOI 10.1016/j.jcae.2018.12.002

18. O. Pirogova, V. Plotnikov, Advances in Intelligent Systems and Computing 1116, 738747 (2020) DOI 10.1007/978-3-030-37919-3_73

19. A.A. Salisu, I.D. Raheem, U.B. Ndako, The inflation hedging properties of gold, stocks and real estate: A comparative analysis, Resources Policy 66, 101605 (2020) DOI 10.1016/j.resourpol.2020.101605

20. Ya. Li, D. Zhu, J. Zhao, X. Zheng, L. Zhang, Effect of the housing purchase restriction policy on the Real Estate Market: Evidence from a typical suburb of Beijing, China, Land Use Policy 94, 104528 (2020) DOI 10.1016/j.landusepol.2020.104528

21. V. Skribans, M. Jurušs, M. Demianchuk, N. Maslii, D. Pastory, Real estate announcements monitoring dataset for Latvia 2018, Data in Brief 28, 105064 (2020) DOI 10.1016/j.dib.2019.105064

22. B. Carmichael, A. Coën, Real estate as a common risk factor in the financial sector: International evidence, Finance Research Letters 32, 101172 (2020) DOI 10.1016/j.frl.2019.04.029

23. A. Eggert, J. Hogreve, W. Ulaga, E. Muenkhoff, Revenue and profit implications of industrial service strategies, Journal of Service Research 17(1), 23-39 (2014) DOI $10.1177 / 1094670513485823$ 